NBER WORKING PAPER SERIES

ON THE PARADOX OF PRUDENTIAL REGULATIONS IN THE GLOBALIZED ECONOMY: INTERNATIONAL RESERVES AND THE CRISIS A REASSESSMENT

\author{
Joshua Aizenman \\ Working Paper 14779 \\ http://www.nber.org/papers/w14779 \\ NATIONAL BUREAU OF ECONOMIC RESEARCH \\ 1050 Massachusetts Avenue \\ Cambridge, MA 02138 \\ March 2009
}

Any views in this articles are that of the author, and do not represent the views of the NBER or any other institutions. The views expressed herein are those of the author(s) and do not necessarily reflect the views of the National Bureau of Economic Research.

NBER working papers are circulated for discussion and comment purposes. They have not been peerreviewed or been subject to the review by the NBER Board of Directors that accompanies official NBER publications.

(C) 2009 by Joshua Aizenman. All rights reserved. Short sections of text, not to exceed two paragraphs, may be quoted without explicit permission provided that full credit, including (C) notice, is given to the source. 
On the Paradox of Prudential Regulations in the Globalized Economy; International Reserves and the Crisis: a Reassessment

Joshua Aizenman

NBER Working Paper No. 14779

March 2009

JEL No. F15,F36,F55

\begin{abstract}
This paper discusses two pertinent issues dealing with the global liquidity crisis -- global prudential regulation reform, and reassessment of using international reserves in the crisis. We point out the paradox of prudential regulations -- while the identity of economic actors that benefited directly from crises avoidance is unknown, the cost and the burden of regulations are transparent. Hence, crises that had been avoided are imperceptible and are underrepresented in the public discourse, and the demand for prudential regulations declines during prolonged good times, thereby increasing the ultimate cost of eventual crises. While the seeds of the present crisis were mostly home grown, international flows of capital magnified its costs. Global financial integration produces the by-product of "regulatory arbitrage" -- capital tends to flow to under regulated countries, frequently resulting in excessive risk taking, in anticipation of future bailout. A coordinated globalized prudential regulation, by increasing the cost of prudential deregulation, may mitigate the temptation to under-regulate during prolonged good-times, thus adding a side benefit. We also analyze the different approaches to the use of reserves during the crisis and what this means for the global financial system. The deleveraging triggered by the crisis implies that countries that hoarded reserves have been reaping the benefits. The crisis illustrates the importance of the self insurance provided by reserves, as well as the usefulness of policies that channel a share of the windfall gains associated with improvements in the terms-of-trade to reserves and sovereign wealth funds. The reluctance of many developing countries to draw down on their reserve holdings raises the possibility that they may now suffer less from the "fear of floating" than from a "fear of losing international reserves", which may signal deterioration in the credit worthiness of a country.
\end{abstract}

Joshua Aizenman

Department of Economics; E2

1156 High St.

University of California, Santa Cruz

Santa Cruz, CA 95064

and NBER

jaizen@ucsc.edu 


\section{On the paradox of prudential regulations in the globalized economy; International reserves and the crisis: a reassessment}

\section{On the paradox of prudential regulations in the globalized economy}

In traditional Chinese medicine, the doctor is paid as long as the patient is healthy. The patient comes in four times a year for a checkup and tune-up, with adjusted lifestyle recommendations. Payment is stopped once the patient is ill. In the US, as long as the economy is healthy, "the financial doctor" in the form of the prudential regulator is considered redundant. Moreover, the prudential regulator is frequently viewed as a spoiler who inhibits growth an development. This is the paradox of prudential regulations in the economy -the better the performance of the regulator, the lower may be the demand for its services. The success of the regulator or a prolonged period of economic tranquility leads to complacency, reducing the demand for his services, inducing under-regulation, which in due course leads to a financial calamity. While the identity of economic actors that benefited directly from crises avoidance is unknown, the cost and the cumbrance of regulations are transparent. Hence, crises that had been avoided are imperceptible and are underrepresented in the political discourse, and the demand for prudential regulations declines during prolonged good times, thereby increasing the ultimate cost of eventual crises.

The 1990s was such a prolonged period of what was perceived as the 'great moderation' of the global economy, a period of remarkable decline in the variability of both output and inflation, reducing the demand for financial regulations. This may explain the growing acceptance during the 1990s-2000s of Greenspan’s seductive “market-stabilizing private regulatory forces” doctrine. Deepening global financial integration, and the growing confidence that global risk diversification reduced systemic risk, sharply lowered the risk premium. The successful private bailout of LongTerm Capital Management (LTCM) in 1998 was taken as a vindication of the efficacy of "marketstabilizing private regulatory forces," where the main role of the Fed is providing coordination services among the private parties involved in the bailout. Yet, the resultant complacency provides the background to the onset of the present crisis -- a calamity akin to a global LTCM on steroids. This time, however, the crisis is too big to be dealt with by private bailouts. The present challenge of rethinking the Global Financial Architecture is to upgrade regulations in ways that recognize the 
paradox of prudential regulations during times of deepening financial integration, while taking into account the emergence of new domestic and foreign players, and new exotic financial instruments.

While the seeds of the present crisis were mostly home grown, international flows of capital magnified its costs. Although it is a mistake to single out any class of foreign players as the key domino, the crisis awakened us to the need to overhaul global financial regulations. Global financial integration produces the by-product of "regulatory arbitrage" - capital tends to flow to under-regulated countries, frequently resulting in excessive risk taking, in anticipation of future bailout. Dealing with “regulatory arbitrage” would benefit by coordinated prudential regulations that preferably apply as equally as possible to domestic and foreign players. Such regulations may be tailored to the risk category and exposure of each player above a minimum size, independent of the player's nationality. This would require a major overhaul of the information gathered by regulators and provide the benefit of setting a minimum global standard on information disclosure, as well as margin and leverage requirements on all financial players above a minimum size. A coordinated globalized prudential regulation, by increasing the cost of prudential deregulation, would mitigate the temptation to under-regulate during prolonged good times, thus adding a side benefit. Thereby, it would act like Odysseus' solution to the temptations of the Sirens: sealing sailors' ears with wax. We review in greater detail the case for comprehensive prudential regulation, and discuss possible implications on the investment practices of sovereign wealth funds [SWFs: savings funds controlled by sovereign governments that hold and manage foreign assets], and international hedge funds.

\section{The nature of financial crises}

Financial crises are as old as financial intermediation, and there is no reason to expect them to disappear. Financial intermediation entails maturity transformation-funding a longer-term tangible investment with shorter-term savings. The essence of a financial crisis is a rapid financial disintermediation due to financial panic. In practice, this involves a "flight to quality," where savers attempt to liquidate assets in financial institutions due to a sudden increase in their perceived risk, moving their savings to safer assets, such as foreign currency and foreign Governments' bonds in developing countries, or currency, gold, and government bonds in the OECD countries. As such, financial intermediation is exposed to financial fragility, in which heightened perceived risk may lead to liquidation, putting the entire financial system at risk. The 
ultimate manifestation of financial crises includes bank failures, stock market crashes, and currency crises, occasionally leading to deep recessions. The economist Hyman Minsky theorized that financial fragility — which is related to the business cycle and to leverage - is a typical feature of any capitalist economy. These considerations are at the heart of the large literature propagated by the stock market crash of 1929 and the Great Depression, including Bernanke’s seminal works on these topics.

Economic reasoning implies that the cost of inappropriate prudential regulation is magnifying the hazard of pre-existing distortions. A vivid example of such a distortion is moral hazard: this arises when investors believe they will be bailed out of their bad investments by the taxpayer, and therefore, have little incentive to undertake proper monitoring of their investments [Heads I win, tails the taxpayer loses.]. In these circumstances, taxpayers subsidize the investment. A frequent rationale for such bailing out is the "too big to fail" doctrine - the cost of systemic risk triggered by the failure of large financial institutions frequently implies that, independent of the ideology of the financial regime, when push comes to shove, tax payers will bail out large financial institutions. The lesson of the Great Depression is that failure to do so is too costly. Minimizing the costs of such bailouts necessitates prudent regulations. The challenge for the regulator is that, due to the nature of market forces and the interaction among market participants, it is impossible to predict the timing of a crisis. Yet, the ugly head of moral hazard is widespread: for example purchasing a house with zero down payment entails private profits when the house appreciates, but social losses when the house depreciates significantly, when the "owner" may walk away from the mortgage, saddling taxpayers and the community with the losses. Similarly, when a bank financing mortgages sells its portfolio to a third party, the bank's profit base switches from the provision of prudential services associated with issuing mortgages into a commission based service, thus reducing the bank's incentives to properly monitor the allocation of credit. Both distortions can be mitigated by proper regulation, including imposing a significant minimum down payment on the homeowner, and capping the share of mortgages that the financing bank can package and resell in the market place. Enforcing these regulations calls for the watchdog to be the party spoiler, described by William McChesney Martin, FED Chairman during the 1950s-1960, as "take away the punch bowl just as the party got going." This activity has been in short supply in recent decades. 


\section{Globalization and financial crises}

While the seeds of the present crisis are domestic, globalization of financial markets may deepen domestic vulnerabilities in under-regulated markets, frequently magnifying the resultant appreciation of domestic assets during economic booms, and assets deflation during busts. This follows the economic logic of the cost of a distortion. In financial autarky, only the pool of domestic saving can feed excessive investment and risk taking induced by the moral hazard distortion. Global financial integration implies that, in the absence of proper regulation, the global pool of saving becomes the feeder of excessive investment [see Aizenman (2002), NBER Working paper \# 8900]. The darker side of financial globalization is that such diversification would expose countries to new vulnerabilities, triggered by the magnification of the moral hazard distortions in countries that under-regulate their markets. This follows the logic of "regulation arbitrage," where the global pool of savings moves towards markets that offer higher private rewards, at a possible cost of a higher bailout bill paid by the domestic taxpayer down the road. These forces imply that the boundaries between domestic and global prudency regulation are getting fuzzier, calling for international coordination of minimum standards, where regulation would deal with risk exposure induced by large financial actors. This requires setting new standards for information disclosure.

\section{On asymmetric information disclosures}

An underappreciated fact is that the regulator in the US imposes stringent disclosure requirements on the non-financial corporate sector, subject to strict confidentiality of the microlevel data disclosed to the regulator. Curiously, there is no comparable information disclosure requirement imposed on the financial sector. To illustrate, the Bureau of Economic Analysis (BEA) does an annual survey of US direct investment abroad. The data collection is confidential, and is based on mandatory surveys conducted by BEA from all the establishments above a critical size. It contains detailed confidential information, including direct investment, employment data, R\&D expenditures, trade in goods and services, and selected financial data. This, and other data collected by Federal agencies, provides the regulator with timely information about the nonfinancial sector. In contrast, there is no comparable attempt to collect data dealing with exposure of the financial sector. As a result, the regulator is frequently in the dark regarding the overall balance sheet exposure of investment banks, hedge funds, and other non-commercial financial intermediaries. The interweaving of credit arrangements implies that the collapse of a major 
financial institution that borrowed from financial intermediaries may trigger systemic risk, where the "too big to fail" doctrine induces a bail out (see the massive bailout of AIG during the Fall of 2008). Hence, any serious regulatory reform may start with upgrading data collection, inducing mandatory periodic confidential reports of the balance sheet exposure of all financial institutions above a minimum size operating in the domestic market.

\section{Global minimum standards for prudential regulation, and the limits to diversification gains}

Having periodically updated confidential information on the balance sheets of all the significant financial players allows for adopting regulations that would better fit future financial challenges. The required regulatory oversight may be performed by each national authority, in ways akin to the role of a doctor in traditional Chinese medicine. Insight about the regulation is gained by recalling a key result of economic theory: the diversification benefits associated with increased globalization can be best obtained by buying a share of a "global fund," composed of all the traded assets of all countries. Such diversification provides the best mechanism for eliminating idiosyncratic risks. Short of engaging in potentially destabilizing zero-sum speculation, large players in the global capital markets would not get, on average, more than the gains associated with holding such global "country funds." Such diversification does not, however, eliminate the exposure to global risks, including exposure to commodity shocks, and global business cycles.

The above suggests that passive portfolio investment in well diversified indexes is welcome, and does not call for any special regulation. All other types of financial positions may be classified into several bins by the degree of exposure to derivatives, short positions, and downside risk that exposes taxpayers to possible bailouts. The greater the taxpayer risk exposure, the higher may be the capital requirement imposed by prudential regulators. The classifications into bins, setting maximum leverage ratios, minimum capital requirements, and other technical details may be revisited periodically, coordinating globally regulations to mitigate damaging "regulatory arbitrage" across borders. To minimize the hazard of a "too big to fail" crises set by under-regulated financial institutions, this coordination applies also for the periodic adjustment of the minimum size of a financial institution under oversight, to ensure that a large enough share of each financial market is regulated. . 


\section{Global prudential regulations, SWFs, Hedge Funds, and other financial actors}

Private analysts put current sovereign wealth fund assets in the range of at \$3 trillion or even higher, projected to grow to as much as $\$ 13$ trillion in the next ten years. This is an amount larger than the current global stock of foreign reserves of about \$6 trillion. While not a new phenomenon, the recent activities and projected growth of SWFs have stirred debate. Much of the discussion has been devoted to the call for individual SWFs to be more transparent about their investment approach. This would require providing more information on the type and amounts of assets they hold, and about their governance structure, by clarifying how decisions are made and monitored. SWFs asset holdings now amount to much less than the funds under management by mutual funds, pension funds, and insurance companies: \$20-30 trillion each. But they are more than the $\$ 1.9$ trillion under management by hedge funds and almost $\$ 1$ trillion by private equity groups [see Aizeman and Glick, FRBSF Economic Letter 2007-38].

There are currently no rules concerning the investment practices of sovereign wealth funds, and both Western governments, and governments with sovereign wealth funds, remain suspicious of each other. These funds have also been instrumental in the subprime crisis - Citigroup, Merrill Lynch, and other major financial players in the US have all received capital infusions from investors in East Asia and the Middle East. As sovereign wealth funds purchase sizeable stakes in some of the most important financial institutions in the world, the lines between economic and foreign policy blur. Apprehension about the size effect of these funds is not new, reflecting the possibility that a large fund may use its market power strategically, potentially leading to greater financial instability, and occasionally benefiting large players. An example of these concerns is the alleged role of large private hedge funds in coordinating speculative attacks on the British pound and other currencies participating in the European exchange rate mechanism in the early 1990s. The extra dimension added by SWFs is the possibility that sovereign investors may use their strategic leverage for narrow nationalistic objectives (Summers, Financial Times, 7-29-2007). These may include supporting domestic "national champion" firms, buying controlling positions in foreign firms with proprietary knowledge, or increasing control of financial and tangible infrastructure abroad (telecommunication, energy, ports, etc.). The adverse political reaction to efforts by China's state-owned oil enterprise to acquire the US oil firm Unocal in 2005, and by the United Arab Emirates' DP World to acquire several major US ports, are well known. The Abu 
Dhabi Investment Authority's recent \$7.5 billion investment in Citigroup prompted less concern, in part because of the Authority's assurances that it would not seek any control or active management. Imposing mandatory periodic reports of the balance sheet exposure of all significant financial institutions would go a long way towards alleviating most of these concerns. In the absence of proper transparency, nationalistic objectives can be advanced indirectly by delegating them to more anonymous third parties, thereby bypassing SWFs. In case of need, greater transparency may allow the regulator to apply a battery of anti-trust and other regulations to deal with what may be deemed improper play by large financial operators. Yet, due to principal-agent problems, some SWFs may be reluctant to increase their transparency. But by no means is resistance to greater transparency unique to SWFs. Hedge funds and private equity managers may share similar views about greater transparency. This, however, is not a reason to prevent a country's national regulators from using mandatory codes of transparency with strict enforcement of confidentiality, on all significant financial players investing in that country. The required transparency may reflect the riskiness of the asset classes involved. This approach provides a menu of choices to SWFs and hedge funds. Some SWFs and other financial intermediaries may opt for passive holdings of well-diversified indexes, with a minimal transparency load. The Norwegian SWF provides a good example of a large fund following what is practically state of the art management practice. The Fund's investment strategy is to maximize financial return with moderate risk, and a high degree of transparency. The long-term strategic allocation, as of June 2008, consisted of equities and fixed income instruments, where equities account for 60 per cent of the Fund's strategic benchmark portfolio. The size of the Fund implies that it owns about 1 per cent of listed European equities and 1/2 per cent of listed equities on a global basis. Such a strategy, as long as it follows a passive investment mode with low frequency adjustments, provides ample opportunities for diversification gains, minimizing the local taxpayer exposure and not exposing the financial system to zero (or negative) sum games. Other players may opt for more narrowly targeted investment strategy, potentially associated with derivatives and leverage. These are precisely the activities that would be regulated. Chances are that improved global prudential regulation will also reduce the use of exotic instruments, but this is what a financial doctor may call for: under-regulated financial players tend to use and abuse these derivatives.

The recent collapse of Iceland, operating in ways akin to a "national hedge fund” illustrate the risk that under-regulated investment, fuelled by excessive leverage, leads down the road to 
political tensions among nations. The recent downfall of Icelandic banks operating in the UK resulted in the application of UK's Anti-Terrorism Crime and Security Act to freeze the British assets of Iceland's Landsbanki bank, triggering political tensions between the UK and Iceland. It will be a global political calamity if a collapse driven by under-regulated SWFs, foreign hedge funds, or other foreign players leads to similar political tensions between larger countries. Yet, under-regulated domestic hedge funds can deliver equal or greater damage, as was vividly illustrated by the collapse of LTCM in the late 1990s, and Lehman Brothers recently. Indeed, when Warren Buffett referred to derivatives as "financial weapons of mass destruction," he had the good sense of focusing on the weapon, and not the nationality of the user. With proper global regulatory design, there would be fewer reasons to discriminate between foreign versus domestic funds. Applying uniform standards of discourse, leverage and capital ratio regulations would level the financial field. While the actual regulation in each country may be the domain of domestic regulators [Treasury, Central Bank, and others like them], the delicate task of coordinating a minimum uniform global standard may be the domain of organizations like the Bank for International Settlements [BIS], the International Monetary Fund [IMF], and similar agencies. Doing it properly may require an overhaul of these organizations, upgrading the share of qualified practitioners and financial economists versed with recent financial innovations, and equipping them with enough resources and talent to track, investigate and regulate the evolving financial innovations as well as the financial mischief that would certainly continue to emerge. Following these steps would reduce "regulatory arbitrage," and the political concerns that views SWFs and foreign capital as the seeds of domestic problems. Refraining from differential nationalist treatment may also facilitate deeper global diversification, while minimizing the downside risk of instability brought about due to excessive leverage. 


\section{Hoarding and using international reserves - a reassessment}

"The shortest period of time lies between the minute you put some money away for a rainy day and the unexpected arrival of rain"

Jane Bryant Quinn

While the United States has been epicentre and origin of the current crisis, the high degree of financial and economic integration has shown the argument that developing countries have “decoupled” from the deterioration of the American economy to be wishful thinking. Developing countries that have, on average, benefited from their integration into the global economy are now facing the darker side of globalisation. The rapid decline in trade, coupled with a flight to quality and the deleveraging of financial flows to developing countries, is putting the adjustment capacities of developing countries to the test. While there is no way to avoid the "stabilisation blues", the hope is that the stronger initial position of developing countries will allow them a softer landing than in previous crises.

\section{Staggering accumulation}

A key development of the last two decades is the proliferation of hybrid exchange-rate regimes in developing countries, where a growing number of countries have adopted managed exchange-rate flexibility, buffered by the accumulation of sizeable foreign reserves. Reserves-to-GDP ratios have increased dramatically, especially in the wake of the Asian financial crisis, most significantly amongst emerging markets. This accumulation was initially led by countries in East Asia, with Latin American and oil-exporting countries joining this trend during the dramatic rise in commodity prices in the early 2000s. The magnitude of accumulation in recent years is simply staggering: reserves increased from about \$1 trillion in 1990 to an estimated $\$ 7$ trillion by June 2008, according to data compiled by the International Monetary Fund. As has been well documented, the accumulation of vast pools of assets in relatively safe, but low-yielding, international bonds has led a number of countries to channel part of their reserves into sovereign wealth funds as they seek higher return on a portion of these reserves.

These developments have triggered intense debate, with many observers calling into question the rationale for the hoarding of large liquidity by relatively poor countries. This article revisits this 
debate in light of the present crisis and the use of reserves during episodes of intense market turmoil.

\section{Theories of reserve accumulation}

It merits taking stock of the theoretical work on reserve holdings and accumulation. Initially, the literature focused on the use of reserves as a buffer stock against external shocks. Accordingly, the optimal level of reserves balanced the macroeconomic adjustment costs incurred in the absence of reserves with the opportunity cost of holding reserves. Although useful, this "buffer stock" model failed to fully account for the hoarding of reserves, especially in the aftermath of the Asian financial crisis. First, under this model, one would expect the greater flexibility of the exchange rates since the early 1990s to reduce reserve accumulation. Second, observers have noted that developing countries frequently borrow at much higher interest rates than what they earn on reserves, which seems counter-intuitive and suggests that other motivations are important too. ${ }^{1}$

\section{Financial integration}

That is not to say that the buffer stock model is irrelevant - indeed it has been highly applicable in the context of financial integration, which has increased emerging markets' exposure to volatile, short-term inflows of capital, subject to frequent sudden stops and reversals. Sudden stops have led to sharp reductions in economic growth, costly banking crises and even social instability. In these circumstances, reserve accumulation is a precautionary measure, providing the domestic authorities with access to hard currency to cover essential expenses and mitigate the adverse consequences of capital flight in times when the country is unable to borrow internationally and the domestic tax capacity is shrinking rapidly. This dynamic has been particularly useful in explaining the accumulation of reserve in the countries affected by the Asian crisis.

The more recent literature has, however, emphasised a number of additional motives to the selfinsurance argument. According to "mercantilist” interpretation, reserves accumulation is a byproduct of promoting exports through exchange-rate intervention, which is needed to create better jobs, thereby absorbing abundant labour in traditional sectors. These perspectives suggest that the

\footnotetext{
${ }^{1}$ The recent literature provided several interpretations for these puzzles. For an overview, see Aizenman, J. (2007).
} 
massive hoarding of reserves by China in recent years is driven by some combination of mercantilist and self-insurance motives. In addition to this, it is likely that "mercantilist hoarding" by one country will induce "competitive hoarding" by other countries in order to prevent any competitive advantage gained by the first country.

\section{The varying responses to the crisis}

The unfolding crisis illustrated the large exposure of emerging markets to the whims of turbulent markets. On impact, the crisis affected diverse countries like Brazil, Chile and South Korea in remarkably similar ways, most notably through a sharp depreciation of the exchange rate. Consider the fact that Chile has a commodity-based currency, Korea is a prime example of a diversified manufacturing country, while Brazil's level of industrialisation is somewhere in-between that of Chile and Korea. Yet, the common denominator of between how these countries have been affected during the crisis is that, by virtue of their financial integration, the flight to quality and deleveraging by investors around the world resulted in capital flight from these economies, as foreign investors opted to reduce their exposure to emerging markets indiscriminately.

\section{Contrasting approaches}

Brazil and Chile have, so far, made very limited active use of their reserves to cushion the inevitable adjustment. Chile's reserves are well above their level of half a year ago, while Brazil's are about the same as a year ago. In contrast, Korea’s reserves have dropped by roughly $\$ 60$ billion in half a year, a decline of about $25 \%$. Indeed, Korea reserves were key to the bailout package it unveiled in the second half of 2008. The centre-piece of the package was a $\$ 100$ billion, three-year government guarantee for banks' debt raised abroad before July 2009. This sum is more than sufficient to cover Korean banks' foreign debt maturing by June 2009, estimated by the Korean Ministry of Strategy and Finance to be about $\$ 80$ billion. Needless to say, the credibility of Korea's bailout package was reinforced by its massive stock of reserves. A similar bailout package was instrumented by the Bank of Russia, though this was done in the context of intensified involvement of the Russian state in managing its vast natural resources, including a willingness to impose what amounted to de facto capital controls. Russia's large stock of reserves before the crisis (exceeding $\$ 600$ billion) has so far allowed it to prevent a complete collapse of its banking system, by resisting larger exchange-rate depreciation through limited capital controls. 
Yet, while Korea and Russia large reserve holdings have undoubtedly been a stabilising force during the current crisis, it is important to caution that these benefits must be weighed against the likely negative incentive effects they create for the long run. The hoarding of reserves may indeed increase the danger of moral hazard associated with the private banking system over-borrowing in foreign currency when actors anticipate such a bailout and imbed it into their borrowing and lending decisions.

Decisions on whether to deploy reserves also depend on the nature of a country's vulnerabilities. Korea's large depreciation, for example, reflects its heavy exposure to deleveraging, given that about half of its stocks foreign-owned at the onset of the crisis, at a time when domestic banks borrowed in hard currencies. While Brazil and Chile were less exposed to deleveraging (owing to lower foreign ownership of their equities), they are highly exposed to deteriorations in the terms of trade for their commodities - Chile due to its reliance on exports of copper, Brazil due to its reliance on exports of agriculture products.

\section{Getting the timing right}

One may ask whether Brazil and Chile have reacted too timidly in refraining from using their reserves more aggressively to cushion the adjustment process. There are several conflicting interpretations of this timidity. As the depth and the duration of the global liquidity crisis and recession is unknown, commodity-exporting countries with relatively low savings rates and little room for fiscal expansion - typical features economies of India and those of Latin America - may be reluctant to draw down their reserves. Policymakers may also prefer that the bulk of the required adjustment take place through a depreciation of the exchange rate, enabling them to save their reserves for even leaner years, if a prolonged period of weakness in their terms of trade occur. Indeed, such adjustment may be a more prudent path than Russia's willingness to spend more than quarter of its reserves to mitigate exchange-rate depreciation at a relatively early stage of the crisis.

Another reason for the limited use of reserves is that the most important intervention and signalling effects may have occurred through the swap lines extended by the Federal Reserve in October 2008 to the central banks of Brazil, Mexico, South Korea and Singapore. Finally, central banks may have been reluctant to draw down their reserves, fearing that it would engender or contribute 
to expectations of further depreciation. This concern applies especially to Latin American countries with limited room for fiscal adjustment.

\section{Swap lines}

Finally, it is important to consider the decision to use reserves against alternatives sources of funding during the current crisis. Indeed, the unprecedented provision of $\$ 120$ billion in swap lines to emerging markets by the Federal Reserve provided welcome relief and an important signal of the willingness of the American authorities to limit the contagion. It would, however, be premature to conclude that the selective credit lines provided by the Fed and the international financial institutions negate the benefits of the earlier hoarding of reserves. In long run, the highly exceptional circumstances leading to the formation of these swap lines in the current crisis are unlikely to apply in the context of more localised sudden stops. Moreover, the uncertainty regarding the coverage and duration of these swap arrangements and delays due to bureaucratic and political costs, suggests that these ad hoc facilities would not suffice in protecting exposed countries from a crisis similar to the Asian financial crisis in the absence of self insurance. They may well have acted as a brake on the sales of US Treasuries, through central banks liquefying their assets, a possibility that may have concerned US authorities.

\section{Placing reserves in a wider context}

An excessive and myopic focus on the question of whether reserves were actively deployed during the crisis or not, miss a key point: countries adjust their policy frameworks and macroeconomic strategies dynamically to best fit the challenges of the day. Here it is useful to think in terms of policymakers' preferred configurations within the Mundell-Fleming "policy trilemma." A fundamental insight of the Mundell-Fleming model is that countries face a policy trilemma, where they may choose any two - but not all three - of the following goals: monetary independence, exchange-rate stability and financial integration.

\section{Middle ground}

Over the last two decades, most developing countries have opted for increasing financial integration, implying that they must either forego exchange-rate stability (if they wish to preserve a degree of monetary independence) or forego monetary independence (if they wish to preserve 
exchange rate stability). ${ }^{2}$ More specifically, a recent paper finds that developing countries have moved towards greater exchange-rate flexibility and deeper financial integration. ${ }^{3}$ Both trends are more pronounced for the emerging markets than for the non-emerging developing countries. Indeed, since the turn of the century, developing countries have converged towards managed exchange-rate flexibility, buffered by sizable reserve holdings. This has enabled them to retain a fair degree of monetary autonomy, even as financial integration continued - a sort of "middleground configuration” within the trilemma.

One may view the response of many developing countries to the current crisis in the context of this new trend - allowing the real exchange rate and monetary policy to take the first brunt of the adjustment. Considering the severity of the crisis in the industrialised economies, the absence of deeper adjustment in emerging markets (so far) is a testament to the degree to which this new middle ground in the trilemma, with proper governance and management, allows for a softer landing in the aftermath of major external events.

\section{A word of caution}

Yet, despite the apparent relative success of this strategy in the initial stages of the crisis, the brunt of the adjustment may yet await us. While exchange-rate and interest-rate adjustments can cushion the landing, a deep crisis frequently ends by testing the fiscal and institutional capacity of countries. The hoarding of reserves may be viewed as being part of a broader buffer policy, which is ultimately impacted by both the fiscal and monetary-policy response.

This point about the interaction between the reserve and the monetary and fiscal policies is vividly illustrated by the proliferation of sovereign wealth funds, mostly by commodity-exporting countries. ${ }^{4}$ Essentially, these funds channel part of the export revenues into accumulating a wider spectrum of foreign assets. A prime example of the fiscal linkages is found in Chile, where by saving the copper dollars in the country's sovereign wealth funds to meet future liabilities rather

\footnotetext{
${ }^{2}$ See Obstfeld, M., Shambaugh, J. and Taylor, A. (2008). "Financial Stability, the Trilemma, and International Reserves”, NBER Working Paper No.14217.

${ }^{3}$ See Aizenman, J., Chinn, M. and Ito, H. (2008). “Assessing the Emerging Global Financial Architecture: Measuring the Trilemma's Configurations over Time”, NBER Working Paper No. 14533

${ }^{4}$ See Aizenman and Glick (2008).
} 
than exchanging them for pesos, the government has eased pressure on the peso. Andrés Velasco, the Chilean finance minister, views the Chilean sovereign wealth funds as part of the same counter-cyclical approach that has been successfully conducted in the country since the 1990s. As of early 2009, the Chilean sovereign wealth funds have accumulated more than $\$ 20$ billion, providing significant scope for fiscal accommodation and softening the deepening recessionary impact of the liquidity and deleveraging crisis.

The choice of the speed of drawing on accumulated resources, both in the form of reserves and as sovereign wealth, is a delicate one. It hinges, amongst other things, on the anticipated future course of the global economy, the domestic adjustment capacity and the degree of financial integration of the country in question. The trade-offs for a country like India differ from those of Chile, as India is less integrated to the global financial system and its government has less room for fiscal adjustment due to its significant and growing fiscal deficits.

As suggested by the Mundell-Fleming framework, countries that are only partially integrated with the global financial system may opt for a different adjustment, as they tend to be less exposed to capital flight and deleveraging. In China, for example, the available information suggests that the crisis has had little discernable impact on reserves (so far). This is in sharp contrast to India, which has accommodated the crisis with sizable downward adjustment in reserves and a significant depreciation of the rupee, both by about 20\% as of December 2008 from their respective peaks earlier in the year.

\section{The renminbi question}

The path of adjustment in China has led to a growing concern among policymakers in the industrialised countries that the crisis may reverse the trend towards the appreciation of the renminbi and lead to the continuation of reserve hoarding by China. If this is the course chosen by China, it would be viewed by the United States and Europe as a reaffirmation of its mercantilist drive. And indeed, there would be considerable risks to China in pursuing this course: the sheer size its exports imply that the scope for China to "export its way out of the crisis" and avoid the domestic adjustment is very limited. The downside risk of mercantilist adjustment by China (or even the perception thereof) is that, if overdone, it would result in competitive depreciations and 
"beggar-thy-neighbour” type trade policies. As the painful experience of the Great Depression showed, such policies further destabilise the global economy. Indeed, prudent adjustment calls for coordinated fiscal expansion.

\section{The future role of reserves}

The present crisis suggests that countries that hoarded reserves have been reaping the benefits. For most developing countries, earlier concerns about excessive hoarding have proved overblown. The crisis illustrates the importance of the self insurance provided by reserves, as well as the usefulness of policies that channel a share of the windfall gains associated with improvements in the terms-oftrade to reserves and sovereign wealth funds. While the recent drop in global commodity prices and equity returns may have reduced the relative appeal of sovereign wealth funds, a resumption of global growth will restore their attractiveness. However, if the "great moderation" is indeed over and volatility in the financial markets remains high, monetary authorities may place greater weight on holding highly liquid reserves as a means of minimising the expected costs of sudden stop, rather than embracing the sovereign wealth approach.

Most emerging markets have been relying mostly on exchange-rate and interest-rate adjustment to accommodate the shocks unleashed by the crisis, making only limited use of reserves to cushion sharp adjustment in their real exchange rate and to signal their credit worthiness in turbulent times. While not a panacea, substantial reserves holdings may be the difference between a soft or hard landing. The willingness to draw down on reserves and the speed at which this is done, reflect a complex interaction between structural and political economy factors.

\section{New fear?}

More generally, the reluctance of many countries to draw down on their reserve holdings raises the possibility that they may now suffer less from the well-known "fear of floating" than from a "fear of losing international reserves", which may signal a deterioration in the credit worthiness of a country. Mitigating this concern may be the prime responsibility of the international financial institutions. Finally, while the mercantilist concerns about China have not been alleviated by the crisis, the magnitude of the global slowdown is likely to be too large for China to attempt exporting its way out of the crisis and completely avoid the domestic adjustment. With proper 
coordination and luck, competitive depreciations and competitive hoardings can be minimised, allowing a coordinated fiscal stimulus to soften the hard landing of the global economy.

\section{References}

Aizenman, J. (2007). "Large Hoarding of International Reserves and the Emerging Global Economic Architecture”, NBER Working Paper No. 13277. Keynote address, The Manchester School, Vol. 76, September, 487-503.

Aizenman, J., Chinn, M. and Ito, H. (2008). "Assessing the Emerging Global Financial Architecture: Measuring the Trilemma's Configurations over Time”, NBER Working Paper No. 14533.

Aizenman, J., and Glick, R. (2008). "Sovereign Wealth Funds: Stylized Facts about their Determinants and Governance”, NBER Working Paper No. 14562.

Obstfeld, M., Shambaugh, J. and Taylor, A. (2008). "Financial Stability, the Trilemma, and International Reserves”, NBER Working Paper No. 14217. 